\title{
Conservation management practices: Success story of the Hog Creek and Sturgeon River watersheds, Ontario, Canada
}

\section{Stang, B. Gharabaghi, R. Rudra, G. Golmohammadi, A.A. Mahboubi, and S.I. Ahmed}

\begin{abstract}
The soil erosion from agricultural watersheds can be reduced by implementation of conservation management practices. In this study, the effectiveness of most popular agricultural best management practices (BMPs) for reducing sediment loads within Hog Creek and Sturgeon River watersheds in Ontario was investigated using measurement of the shift in the sediment rating curves from pre-BMP (1989 to 1993) to post-BMP (2004 to 2008) implementation periods. The data from the water quality monitoring program for the Hog Creek and the Sturgeon River watersheds over this decade of extensive conservation management program implementation showed significant reductions in the sediment loads of $49 \%$ for $\mathrm{Hog}$ Creek and $41 \%$ for the Sturgeon River. The results showed that the most widely adopted BMPs that greatly influenced the overall removal in sediment loads were stream bank fencing, no-till farming, and vegetative buffer strips. Overall, the outcome of the study recommends these promising practices to protect and improve receiving water quality. The practical novel technique presented in this study for quantification of the overall long-term water quality benefits of conservation management practices can be an integral part of an adaptive strategy for a watershed-scale BMP implementation program.
\end{abstract}

Key words: best management practices—conservation—management—sediment rating curve-Severn Sound—water quality

\begin{abstract}
Clean water is essential for the health of watersheds and the rivers and lakes to which they contribute (Ritter and Shirmohammadi 2001). Ontario has almost one-third of Canada's population and thus its water resources need to be protected and managed in a safe and sustainable manner. Nonpoint source pollution and downstream flooding from agricultural watersheds can be controlled by implementing best management practices (BMPs) at strategic locations (Hernandez and Uddameri 2015; Tuppad et al. 2010a; Lam et al. 2011; Qi and Altinakar 2011a,b; Lemke et al. 2011; Giri et al. 2012; Sommerlot et al. 2013; Artita et al. 2013; Lizotte et al. 2014; Yang et al. 2014; Trenouth and Gharabaghi 2015). Soil erosion from agricultural watersheds can be reduced by adoption of sediment control practices, such as conservation tillage, crop rotation, vegetative filter strips, terraces, and grassed waterways (Baker et al. 2006; Zhou et al.
\end{abstract} accrue as a result of the implementation of given practice at a given place in the watershed (Mostaghimi et al. 1997; Bracmort et al. 2004; Nietch et al. 2005; Prokopy et al. 2008; Arabi et al. 2007; Karamouz et al. 2010; Yang et al. 2012; Grady et al. 2013; Jang et al. 2013; Giri et al. 2014; Sattar and Gharabaghi 2015). The effectiveness of practices and optimization of their implementation is important to reduce the costs (Easton et al. 2008; Daroub et al. 2009; Bumbudsanpharoke et al. 2009; Chaubey et al. 2010; Giri et al. 2014; Atieh et al. 2015; Liu et al. 2015b; Brooks et al. 2015). The economic benefits and costs of the adoption of BMPs have been evaluated by several researchers (Maringanti et al. 2011; Yuan et al. 2002; Wu et al. 2006; Smith et al. 2007; Tuppad et al. 2010b; Lee et al. 2010;
Gassman et al. 2010; Jang et al. 2013; Jeffrey et al. 2014; Perry-Hill and L. Prokopy 2014; Alemayehu et al. 2014; Kurkalova et al. 2015).

Performance evaluation of BMPs on watershed scale can be done via monitoring and/or modeling. Monitoring is always a better and preferred option, but it is an expensive and time-consuming method and yields only site-specific results for a given set of climatic conditions. Models can be used to evaluate the impacts of BMPs on water quality under scenarios that would be difficult, if not impossible, to study experimentally (Bracmort et al. 2006; Lin et al. 2009; O'Connor and Rossi 2009; Yang et al. 2009a; Busteed et al. 2009; Gazendam et al. 2009; Daggupati et al. 2011; Yang et al.2012; Dechmi and Skhiri 2013; Liu et al. 2015b).

Inamdarm and Naumov (2006) estimated sediment yields of the Buffalo River watershed using the Soil and Water Assesment Tool (SWAT) model. They found that Cazenovia Creek had the highest contribution of total sediment yield to the Buffalo River watershed due to steeper slopes. Smith et al. (2015) examined several conservation practices, including single and combined, which were simulated at the field scale using the Agricultural Policy/Environmental eXtender (APEX) model. They found cover crops and forage to be the most effective single conservation practices.

In 1987, the International Joint Commission (IJC), an organization that has members from both Canada and the United States, listed Severn Sound and other areas along the Great Lakes with degraded water quality as Areas of Concern (AOC). The actions to restore a healthy environment for the community involve the development of
Conrad Stang is a water resources engineer with NOVATECH Engineers, Planners and Landscape Architects in Ottawa, Ontario. Bahram Gharabaghi is an associate professor of engineering in the School of Engineering at the University of Guelph in Guelph, Ontario. Ramesh Rudra is a professor of engineering in the School of Engineering at the University of Guelph in Guelph, Ontario. Golmar Golmohammadi is a postdoctoral research associate in the School of Engineering at the University of Guelph in Guelph, Ontario. Ali Akbar Mahboubi is a professor in the Department of Soil Science in the College of Agriculture at Bu-Ali Sina University in Hamadan, Iran. Syed Imran Ahmed is a postdoctoral research fellow in the School of Engineering at the University of Guelph in Guelph, Ontario. 
a Remedial Action Plan (RAP) administered by the Severn Sound Environmental Association (SSEA 1993). The RAP provided the opportunity to upgrade the sewage treatment plants and implement extensive conservation management programs to improve the water quality within the region. The most commonly utilized BMPs included streambank fencing; increased forest cover; riparian buffers; upgraded manure storage facilities; milk house wash water treatment, nutrient management plans; runoff diversion systems and windbreaks/shelterbelts; and cropland protection practices, such as crop rotation, cover crops, conservation tillage, and no tillage (SSEA 2002). In 2003, after the SSEA reached its goal of improving the water quality and restoring wildlife habitat in Severn Sound, the IJC delisted the Severn Sound watershed as an AOC.

The main objective of this study was to analyze and document the success story of the implementation of extensive conservation management practices within Hog Creek and Sturgeon River watersheds, which resulted in significant improvements in regional water quality. This study also highlights opportunities for further water quality improvements through implementation of additional conservation management practices.

\section{Materials and Methods}

Description of the Study Area for Hog Creek and Sturgeon River. The gross drainage area for Hog Creek is $65.2 \mathrm{~km}^{2}(25.17$ $\mathrm{mi}^{2}$ ) and the geographic location at the outlet is approximately $44^{\circ} 43^{\prime} 33^{\prime \prime} \mathrm{N}$ latitude $79^{\circ} 46^{\prime} 44^{\prime \prime}$ W longitude (figure 1). Hog Creek flows north from Oro-Medonte Township to Tay Township and outlets into Hog Bay. The creek has shaped a shallow channel in the flat-floored clay valley; the clay flats are of glaciolacustrine origin (Singer et al. 2002). Hog Creek is fed by springs along the valley sides, which feed into 15 first-order tributaries and many second and third-order tributaries (Singer et al. 2002).

The sides of the valleys are composed mainly of till with some stratified sand and gravel, which originated from ice movement during the last glacial retreat (Singer et al. 2002). Using the Local Minimum Method associated with the Ontario Flow Assessment Tool (OFAT), Hog Creek has an average base flow Index (BFI) of 0.44 (ratio of average base flow to average stream flow), indicating that groundwater is a regular con- tributor to the stream flow (Neff et al. 2005). The prominent land use in the Hog Creek watershed for the past $50+$ years is agriculture and woodlots. However, small cottages occupy the reinforced banks near the outlet (SSEA 2002), with the majority of land use across the watershed under hay system followed by idle lands and pasture.

The Sturgeon River flows north from a hilly plateau near Hillsdale to Tay Township and outlets into Sturgeon Bay (figure 1). The gross drainage area for the Sturgeon River is $103 \mathrm{~km}^{2}\left(39.77 \mathrm{mi}^{2}\right.$ ) with a geographic location at the outlet of $44^{\circ} 43^{\prime} 49^{\prime \prime} \mathrm{N}$ latitude $79^{\circ} 43^{\prime} 11^{\prime \prime} \mathrm{W}$ longitude. The headwaters are located in Springwater Township and OroMedonte Township. The river is located on the flat floor of a steep valley that was created during the last glacial retreat. This created many ice-contact deposits of glaciofluvial and glaciolacustrine origin (Singer et al. 2002). These deposits consist of fine to coarse-grained sand, gravelly sand, and gravel with minor amounts of silt, clay, and till (Singer et al. 2002). The Sturgeon River has a large influence of groundwater base flow, which feeds into its ten first-order tributaries and a few second-order tributaries (Singer et al. 2002). The influence of groundwater helps to dilute total phosphorous $(\mathrm{P})$ and chloride concentrations within the river (SSEA 2002). Similar to the Hog Creek watershed, the prominent land use for the past 50 years in the Sturgeon River watershed is agriculture and preserved forests with the majority of hay followed by idle lands and pasture.

Land Use in the Study Areas. It is necessary to take into account both the land use and the land cover pattern simultaneously in the study of the impacts of land use on the water quality (Houlahan and Findlay 2004). Key influencing factors changing the watershed and leading to more runoff plus erosion are the changes in land cover and land management practices (Bai 2010). Agricultural practices, including tillage, fertilization, and residue management, can affect surface runoff, soil erosion, and nutrient cycling. These processes, in turn, may affect water quality (Mueller-Warrant et al. 2012). However, table 1 presents land use for Hog Creek and Sturgeon River watersheds using census data for the pre-BMP versus post-BMP periods. The land use change in these watersheds over the study period has been negligible (slight increase in row crops and slight decrease in hay/pasture). Row crops typically have higher sediment loads per unit area compared to hay/pasture land cover.

Climate Change in the Study Area. Climate change is another possible factor that can affect the water quality of an area with time. Therefore, some studies were reviewed regarding changes due to climate. However, several studies, including Aber et al. (1995), Zhang et al. (2000), Whitfield and Cannon (2000), Van Liew et al. (2013), and most recently Asnaashari et al. (2015), analyzed historic records as well as projected future data to predict rate of change in precipitation and found that it is very slow and gradual in southern Ontario. They found a gradual "change per decade" of 1\% increase in total precipitation, $2 \%$ increase in rainfall, $6.7 \%$ decrease in snowfall, $2.3 \%$ increase in potential evapotranspiration, $5 \%$ increase in streamflow during winter months, and 2.5\% decrease in streamflow during the summer months over the study period. All of these percentage changes are per decade; therefore, during the two decades of the study period we could expect little change (less than 5\%) in the sediment loads due to climate change and can safely assume that the bulk of the removal in sediment load was due to the BMP implementation.

\section{Streamflow Monitoring Program.} Historical stream flow data was provided by the Water Survey of Canada (WSC), which used a Stevens Type A-35 Water Level Recorder for the monitoring stations at Hog Creek (WSC Station ID 02ED017) and Sturgeon River (WSC Station ID 02ED018). The WSC still maintains the station at Hog Creek, but discontinued the station in the Sturgeon River on July 28, 1998. For the period between July 16, 2007 , and October 31, 2008, two HOBO Level Loggers (Onset Computers, Massachusetts, United States) were installed in the existing WSC stilling well at the Sturgeon River to collect atmospheric and water pressure. The data collected by the HOBO Level Loggers was converted to water level data, which was calibrated using a staff gauge installed underneath the bridge directly upstream from the WSC stilling well on Rosemount Road. To convert water level data to flow data, the latest WSC stage-discharge curve for the Sturgeon River was updated using stream gauging via a Valemont electromagnetic flow sensor.

Water Quality Monitoring Program. Water quality data collected in this study 


\section{Table 1}

Land use comparison using census data for pre-best management practices (BMP) versus post-BMP period.

\begin{tabular}{|c|c|c|c|c|c|c|c|c|c|}
\hline \multirow[b]{2}{*}{ County } & \multicolumn{3}{|c|}{ Row crops (km²) } & \multicolumn{3}{|c|}{ Hay/pasture $\left(\mathbf{k m}^{2}\right)$} & \multicolumn{3}{|c|}{ Total area of farms $\left(\mathbf{k m}^{2}\right)$} \\
\hline & 1996 & 2001 & $\begin{array}{l}\text { Change } \\
(\%)\end{array}$ & 1996 & 2001 & $\begin{array}{l}\text { Change } \\
(\%)\end{array}$ & 1996 & 2001 & $\begin{array}{l}\text { Change } \\
(\%)\end{array}$ \\
\hline Springwater & 195 & 207 & 5.5 & 35 & 26 & -32.0 & 269 & 278 & 3.2 \\
\hline Oro-Medonte & 140 & 159 & 11.5 & 48 & 44 & -7.9 & 250 & 255 & 1.9 \\
\hline Tiny & 51 & 57 & 11.0 & 15 & 14 & -8.0 & 91 & 90 & -1.5 \\
\hline Tay & 27 & 24 & -11.4 & 11 & 11 & 1.1 & 53 & 48 & -10.4 \\
\hline Total & 415 & 448 & 7.4 & 110 & 97 & -13.6 & 665 & 672 & 1.1 \\
\hline
\end{tabular}

\section{Figure 1}

Severn Sound watersheds (SSEA 2010).

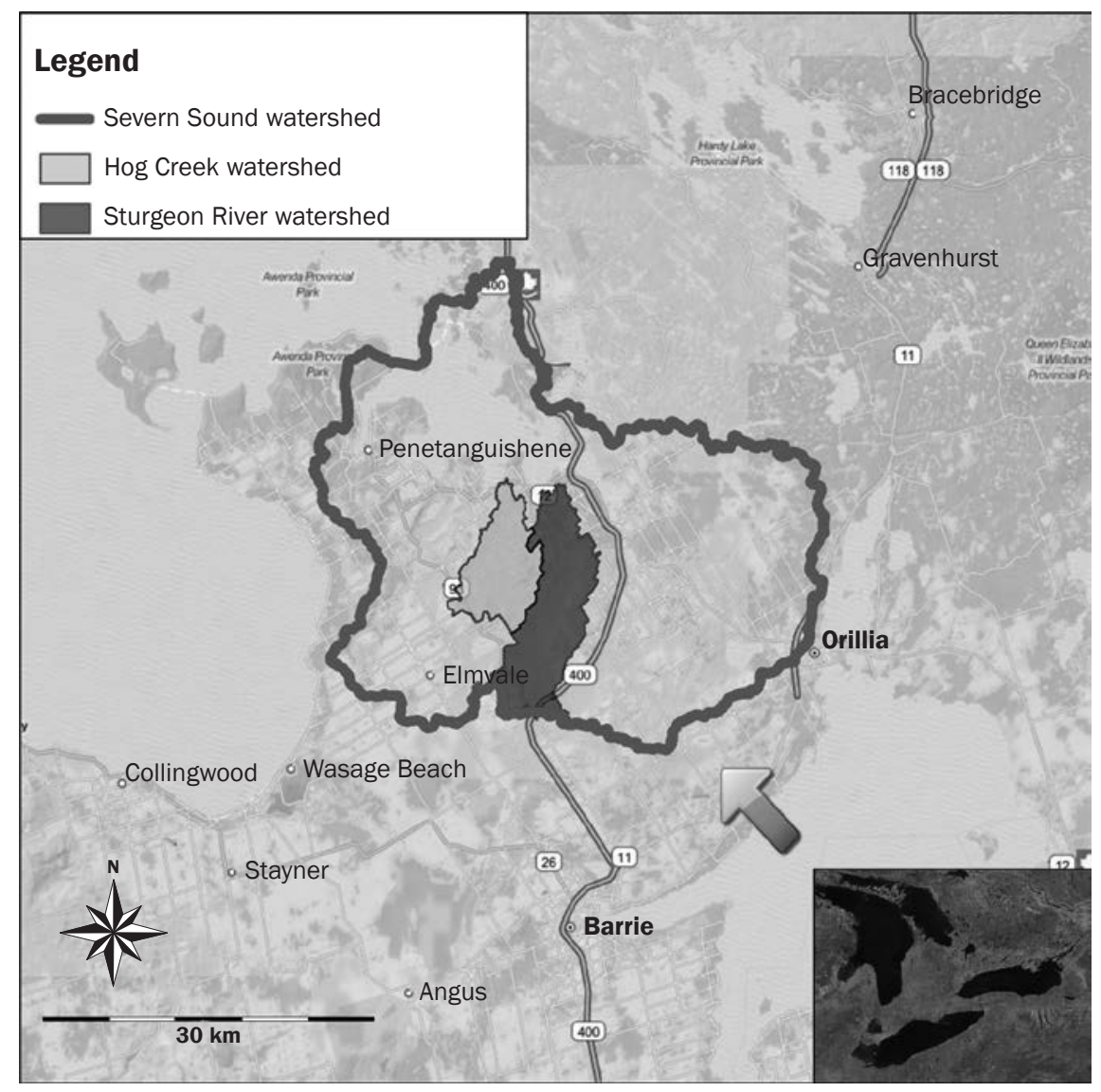

utilized both an instantaneous sampler (open bottle sampler) and isokinetic sampler (DH48) to compare both techniques. Samples were taken during or within 24 hours of a rain event. The instantaneous sampler used in the field investigation was a standard $0.5 \mathrm{~L}$ (16.9 oz) open sample bottle used by the Ministry of the Environment for the Provincial Water Quality Monitoring Program in Ontario. The isokinetic sampler used for this study was the DH-48, which is a rod-suspended sampler that has an aluminum casting that partially encloses a $0.5 \mathrm{~L}$ rigid plastic sample container. Samples were analyzed at the University of Guelph's Environmental and Water Laboratories according to the US Environmental Protection Agency (USEPA) standard outlined in technical document 160.2 (Guo 2008). Samples were filtered through $0.45 \mu \mathrm{m}$ cellulose fiber filters, and residual fines were washed onto the filter paper from the pump apparatus with distilled water. Filtered samples were oven dried for one hour at $105^{\circ} \mathrm{C}\left(221^{\circ} \mathrm{F}\right)$ and reweighed on an analytical balance according to the USEPA standard outlined in technical document 160.2 (Guo 2008).

Best Management Practices Sediment Removal Efficiency. Based on a comprehensive list of conservation management practices found in the Canada-Ontario Farm Stewardship program, a detailed review of the literature was examined from both composite and individual literature sources. The BMPs were reviewed for their effectiveness for reducing loads of pollutants commonly found in freshwater streams.

The findings of all the literature were synthesized into simple tables for easy comparison and future application. Table 2 shows the results of the BMP literature review and summarizes the known sediment removal efficiency for 25 types of BMPs found to improve water quality.

The results from the literature review (table 2) show that a higher mean or median value for each BMP represents greater ability to reduce sediment, while a lower mean or median value indicates that the BMP is less effective at reducing a particular pollutant.

Development of Sediment Rating Curves. Sediment rating curves are empirical relations between water discharge (independent variable) and sediment concentration or sediment load (dependent variable). Sediment rating curves can be created for instantaneous, daily, monthly, seasonal, annual, or event-based data and are often developed from logarithmically transformed data. The sediment rating curve is thus expressed as a linear or nonlinear power function based upon the stream's characteristics (Equation 1; Glysson 1987):

$Q_{s}=a Q_{w}{ }^{b}$, 
Table 2

Published best management practices (BMP) sediment removal efficiency mean (median).

\begin{tabular}{|c|c|c|}
\hline BMP & $\begin{array}{l}\text { Sediment } \\
\text { removal efficiency } \\
\text { mean (median) }\end{array}$ & Source material \\
\hline No-tillage & $92(85)$ & $\begin{array}{l}\text { *Merriman et al. 2009; *Dinnes 2004; *DPRA Inc. 1989; *Yagow et al. 2002; } \\
\text { Bryant et al. 2008; *Cook 1999; *Schnepf and Cox 2006. }\end{array}$ \\
\hline Diversion channels/runoff control & $83(68)$ & $\begin{array}{l}\text { *SERA } 17 \text { 2009; *Cook 1999; *Merriman et al. 2009; *Dinnes 2004; *DPRA Inc. } \\
\text { 1989; *Pennsylvania State University 1992; *Yagow et al. 2002; *Ghebremichael } \\
\text { and Watzin 2008. }\end{array}$ \\
\hline Wetland habitat restoration & $80(80)$ & *SEPA 2010; *Merriman et al. 2009; *Dinnes 2004; *Yagow et al. 2002. \\
\hline Sediment control basins & $76(75)$ & Boyer 2006; *Cook 1999; *DEPRA Inc. 1989; *Yagow et al. 2002; *SEPA 2010. \\
\hline Vegetative buffer strips & $74(69)$ & $\begin{array}{l}\text { *Cook 1999; *SERA } 17 \text { 2009; *Schnepf and Cox 2006; Mikkelsen and Gilliam } \\
\text { 1995; Daniels and Gilliam 1996; Patty et al. 1997; Robinson et al. 1996; Heathwaite } \\
\text { 1998; *SWCS 2008; *Merriman et al. 2009; *Dinnes 2004; *SEPA 2010; *Ghe- } \\
\text { bremichael and Watzin 2008; *Gitau et al. 2005; Boyer 2006; *Wenger 1999; } \\
\text { * Melcher and Skagen 2005. }\end{array}$ \\
\hline Relocation of livestock & $70(70)$ & *Dinnes 2004; Lugbill 1990; Meals 2001 *SEPA 2010. \\
\hline Ditch bank/gully stabilization & $70(59)$ & $\begin{array}{l}\text { *Merriman et al. 2009; *Cook 1999; *DPRA Inc. 1989; *SEPA 2010; *SWCS 2008; } \\
\text { *Yagow et al. } 2002 .\end{array}$ \\
\hline Terraces & $65(61)$ & *SERA 17 2009; *Merriman et al. 2009; *DPRA Inc. 1989; *SEPA 2010. \\
\hline Wastewater treatment & $64(64)$ & *SEPA 2010. \\
\hline Conservation tillage & $55(56)$ & $\begin{array}{l}\text { *SERA } 17 \text { 2009; *Cook 1999; *SWCS 2008; *Merriman et al. 2009; *Dinnes 2004; } \\
\text { *DPRA Inc. 1989; *Yagow et al. 2002; Bryant et al. 2008; *Ghebremichael and } \\
\text { Watzin 2008; *Gitau et al. 2005. }\end{array}$ \\
\hline Streambank fencing & $40(47)$ & *Schnepf and Cox 2006; *Cook 1999; *SWCS 2008; *Merriman et al. 2009. \\
\hline Alternative water source & $39(49)$ & *Schnepf and Cox 2006; *SWCS 2008. \\
\hline Cover crops & $35(44)$ & $\begin{array}{l}\text { *Merriman et al. 2009; *Dinnes 2004; *Yagow et al. 2002; *SEPA 2010; *SWCS } \\
\text { 2008; *Schnepf and Cox } 2006 .\end{array}$ \\
\hline Reforestation & $14(27)$ & *Merriman et al. 2009; SWCS 2008. \\
\hline Improved manure spreading & $10(10)$ & *Merriman et al. 2009; *Dinnes 2004. \\
\hline
\end{tabular}

Notes: Not all of the data used in this table are from Ontario studies. N/A = Not applicable.

*Indicate sources that included synthesis, evaluation, or reporting of multiple studies or documents.

where $Q$ is suspended sediment discharge $\left(\mathrm{t} \mathrm{d}^{-1}\right), Q_{w}$ is water discharge $\left(\mathrm{m}^{3} \mathrm{~s}^{-1}\right), a$ is scaling factor, and $b$ is exponent.

The sediment rating curve is often developed for sites with long-term record of stream flow measurements. One common use of sediment rating curves is to generate power equations to estimate unknown daily sediment loads between sampling intervals and determine monthly or annual sediment loads (Livesey 1975). Figure 2 presents a sample of a few sediment rating curves for Ontario watersheds. Sediment rating curves for Hog Creek and Sturgeon River were created using measured stream flow and sediment data. These data sets were used by combining stream flow with sediment concentration to calculate the total sediment load for the sample. Sediment rating curves for the instantaneous and isokinetic sampler were evaluated separately to analyze the periods before and after BMPs were imple- mented. Monthly sediment rating curves were also derived from daily values from the power equations for all of the combined data for each period. The equation from the line of best fit was used to compute daily sediment load and the average of each month was used to create an average monthly value.

Hydrologic Model Development. The main limitation of the new technique for the assessment of the overall long-term water quality benefits of conservation management practices is the required streamflow and water quality monitoring data from pre- to post-BMP periods to determine the shift in the sediment rating curves. For watersheds with limited monitoring data, it is common practice to develop and calibrate/ validate a watershed-scale water quality model (e.g., SWAT, AGricultural Non-Point Source Pollution [AGNPS], Hydrological Simulation Program-Fortran [HSPF], or Canadian Nutrient and Water Evaluation
Tool [CANWET]) to fill-in monitoring data gaps (if necessary) and validate the observed trends using simulated data. In this study we have selected CANWET model, as it is a Canadian model that is easier to setup due to compatibility with Canadian data sets (Das et al. 2008; Rudra et al. 2010; Singh et al. 2012; Ahmed et al. 2013; Chapi et al. 2014; Liu et al. 2015a).

The CANWET model is an empirical semidistributed model for surface water and solid-phase sediment and nutrient loadings, which means it combines multiple land use/ cover scenarios (Greenland 2007). Input parameters used to calculate watershed hydrology and erosion are area-weighted calculations created by clipping the land use, soils, and topography geographical information system (GIS) layers. CANWET model predicts a continuous streamflow using the daily weather data based on the water balance 


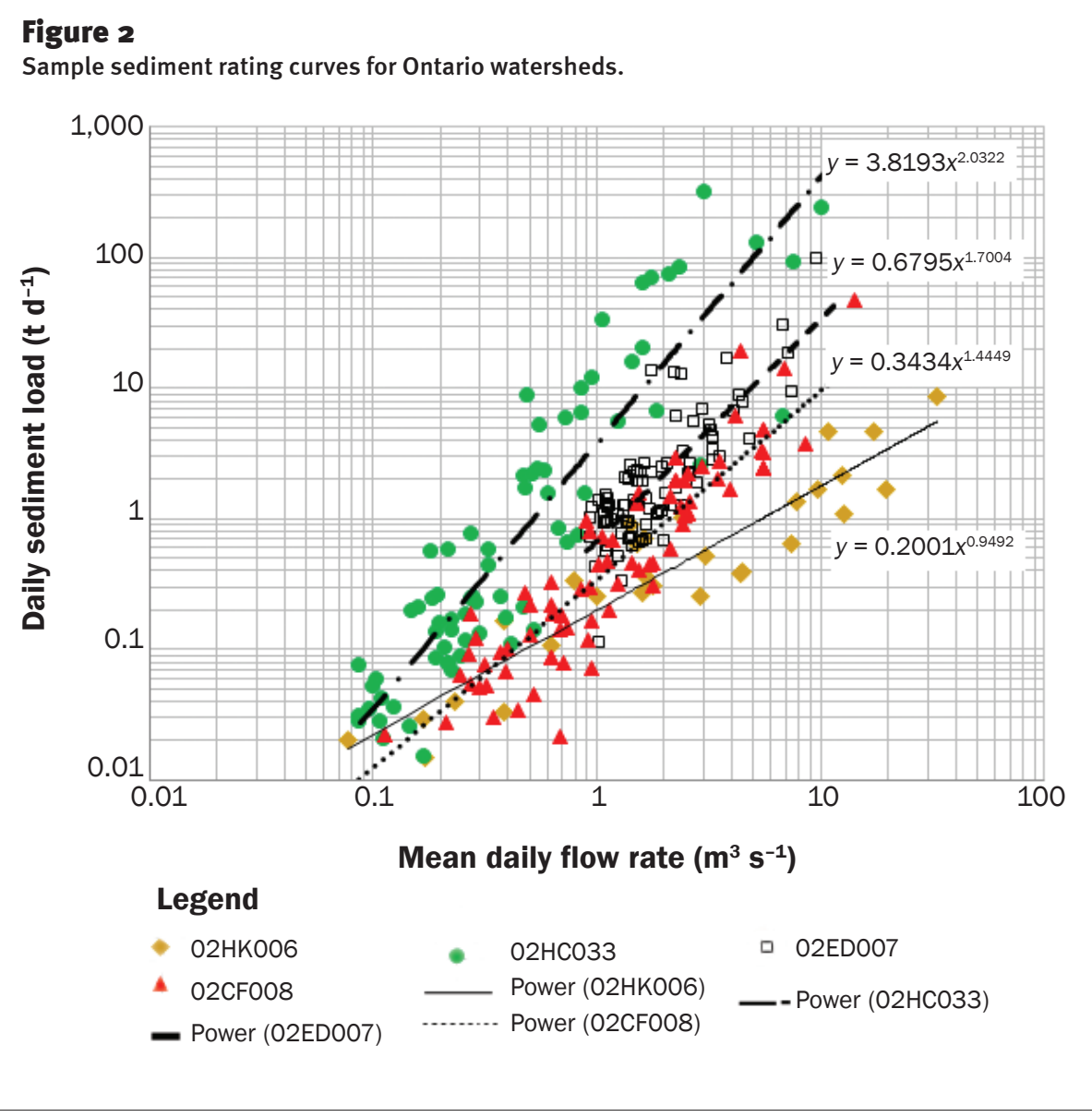

calculations. The surface runoff is calculated using SCS curve number approach.

The model uses the universal soil loss equation (USLE; Wischmeier and Smith 1965) for soil erosion calculation. Evapotranspiration is determined by the Hamon method (1961), using daily weather data and land use cover factor. The model computes the daily water balance for both unsaturated and saturated zones. The infiltration is simply calculated as the precipitation minus surface runoff and evapotranspiration. CANWET model is also a lumped model for lateral groundwater discharge and dissolved-phase nutrient loadings. Surface loadings of runoff, sediment, and solid-phase nutrients are generated for each source area and aggregated to determine watershed totals.

Lateral groundwater discharge and dissolved phase loadings are lumped for the entire watershed. There is no internal spatial routing routine as water quality loads from each land use layer are aggregated to present a total watershed load; although, this functionality has been added with later versions. Output results are presented daily for streamflow, whereas results for hydrology,
Stream bank fencing was applied to control sediment load to many of the streams that intersected with agricultural lands containing livestock, thus producing an estimated overall sediment removal efficiency of $28.4 \%$ for Hog Creek and $28.8 \%$ for the Sturgeon River. The vegetative buffer strips were found to be the second effective BMP followed by ditch bank/gully stabilization for Hog Creek. For Sturgeon River, ditch bank/gully stabilization was the second best practice followed by vegetative buffer strips for sediment load. No-tillage has the highest sediment removal efficiency (92\%), although this was not widely applied from pre-BMP to post-BMP period due to technical challenged that it posed for the growers and thus the overall sediment removal contribution due to this BMP in this period was just 5\%.

Sediment Rating Curves. The sediment rating curves for both Hog Creek and Sturgeon River watersheds are presented in figures 3 and 4 . The amplitude (scaling factor) from the sediment rating curve using the power equation was greatly reduced during the post-BMPs period (2004 to 2008) when compared with the pre-BMP period (1989 to 1993).

Canadian Nutrient and Water Evaluation Tool Simulation Results-Monthly Sediment Load Simulations. CANWET model was calibrated and validated to adequately simulate sediment loads. The simulation results of monthly sediment loads during the calibration and validation periods are presented in figures 5 through 8 .

In general, the results indicate a close agreement between the observed and simulated sediment loads during both calibration and validation periods in Hog Creek and Sturgeon River watersheds. However, the model underestimated the sediment loads during the March and April snowmelt events of the year 1990 in both Hog Creek and Sturgeon River watersheds. The streamflow under-prediction by the model can be attributed to error in precipitation data. The performance of the model to simulate stream flow for the calibration and validation periods was further examined by using statistical criteria. The statistical indices for the comparison of monthly observed and simulated flows are presented in tables 4 and 5 .

Based on the statistics, the model accurately represents the sediment loads for both watersheds and for both BMP periods. The model performed better for the post-BMP 
Table 3

Overall sediment load removal efficiency for best management practices (BMPs) applied within the Hog Creek and Sturgeon River watersheds from pre-BMP (1989 to 1993) to post-BMP (2004 to 2008) period.

\begin{tabular}{|c|c|c|c|c|c|c|c|}
\hline \multirow[b]{2}{*}{ BMP } & \multirow[b]{2}{*}{$\begin{array}{l}\text { BMP } \\
\text { sediment } \\
\text { removal } \\
\text { efficiency (\%) }\end{array}$} & \multicolumn{3}{|l|}{ Hog Creek } & \multicolumn{3}{|l|}{ Sturgeon River } \\
\hline & & $\begin{array}{l}\text { BMPs applied } \\
\text { pre-BMP period } \\
\text { (1989 to 1993; \%) }\end{array}$ & $\begin{array}{l}\text { BMPs applied } \\
\text { post-BMP period } \\
\text { (2004 to 2008; \%) }\end{array}$ & $\begin{array}{l}\text { Overall } \\
\text { sediment load } \\
\text { removal from } \\
\text { pre to post }(\%)^{*}\end{array}$ & $\begin{array}{l}\text { BMPs applied } \\
\text { pre-BMP period } \\
\text { (1989 to 1993; \%) }\end{array}$ & $\begin{array}{l}\text { BMPs applied } \\
\text { post-BMP period } \\
\text { (2004 to 2008; \%) }\end{array}$ & $\begin{array}{l}\text { Overall } \\
\text { sediment load } \\
\text { removal from } \\
\text { pre to post (\%)* }\end{array}$ \\
\hline Cover crops & 33 & 10 & 11 & 0.3 & 10 & 11 & 0.3 \\
\hline $\begin{array}{l}\text { Stream bank } \\
\text { fencing }\end{array}$ & 40 & 20 & 91 & 28.4 & 20 & 92 & 28.8 \\
\hline Reforestation & 14 & N/A & 7 & 1 & N/A & 5 & 0.7 \\
\hline $\begin{array}{l}\text { Vegetative buffer } \\
\text { strips }\end{array}$ & 74 & $\mathrm{~N} / \mathrm{A}$ & 11 & 8.1 & $\mathrm{~N} / \mathrm{A}$ & 8 & 5.9 \\
\hline $\begin{array}{l}\text { Ditch bank / } \\
\text { gully stabilization }\end{array}$ & 70 & 11 & 20 & 6.3 & 11 & 20 & 6.3 \\
\hline No-tillage & 92 & 7 & 12 & 4.6 & 7 & 12 & 4.6 \\
\hline Conservation tillage & 55 & 11 & 19 & 4.4 & 11 & 19 & 4.4 \\
\hline Total & & & & 53.2 & & & 51.1 \\
\hline
\end{tabular}

*Calculated by (increase in BMPs applied from pre- to post-BMP Period) $\times($ BMP sediment removal efficiency) for Hog Creek and Sturgeon River.

Figure 3

Sediment rating curves for Hog Creek for the pre-best management practice (BMP) and the post-BMP periods.

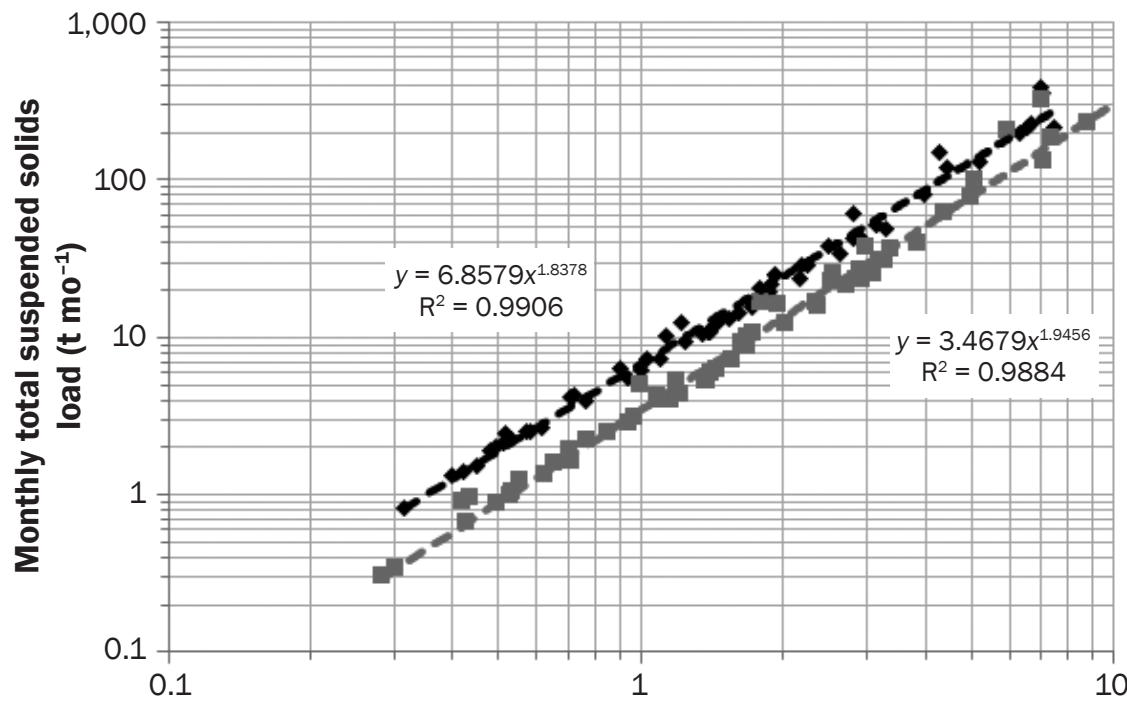

Mean monthly streamflow $\left(\mathrm{m}^{3} \mathrm{~s}^{-1}\right)$

\section{Legend}

- Pre-BMPs: 1989 to 1993

Post-BMPs: 2004 to 2008 period for both watersheds for sediment. The statistical coefficients show that the model performed slightly better in the calibration period than in the validation period.

\section{Summary and Conclusions}

This study presents a novel method for quantification of the overall long-term water quality benefits of conservation management practices (i.e., reduction in sediment loads) within a watershed by quantifying the shift in the sediment rating curves from preBMP to post-BMP implementation periods. Watershed modeling was also performed for the pre- and post-BMP periods using CANWET model. The models performed well when compared both statistically and graphically with observed data. The average monthly simulated results had almost the same overall sediment reduction efficiency as calculated using the shift in sediment rating curves. However, it is much faster and easier to calculate the overall long-term water quality benefits of conservation management practices using the proposed new method compared to the time-consuming and advanced experience required for proper watershed-scale water quality modeling using SWAT, AGNPS, HSPF, or CANWET models (Das et al. 2008; Rudra et al. 2010; Singh et al. 2012; Ahmed et al. 2013; Chapi et al. 2014; Liu et al. 2015a).

However, the main limitation of the new technique for the assessment of the overall long-term water quality benefits of conservation management practices is the required streamflow and water quality monitoring 


\section{Figure 4}

Sediment rating curves for Sturgeon River for the pre-best management practice (BMP) and the post-BMP periods.

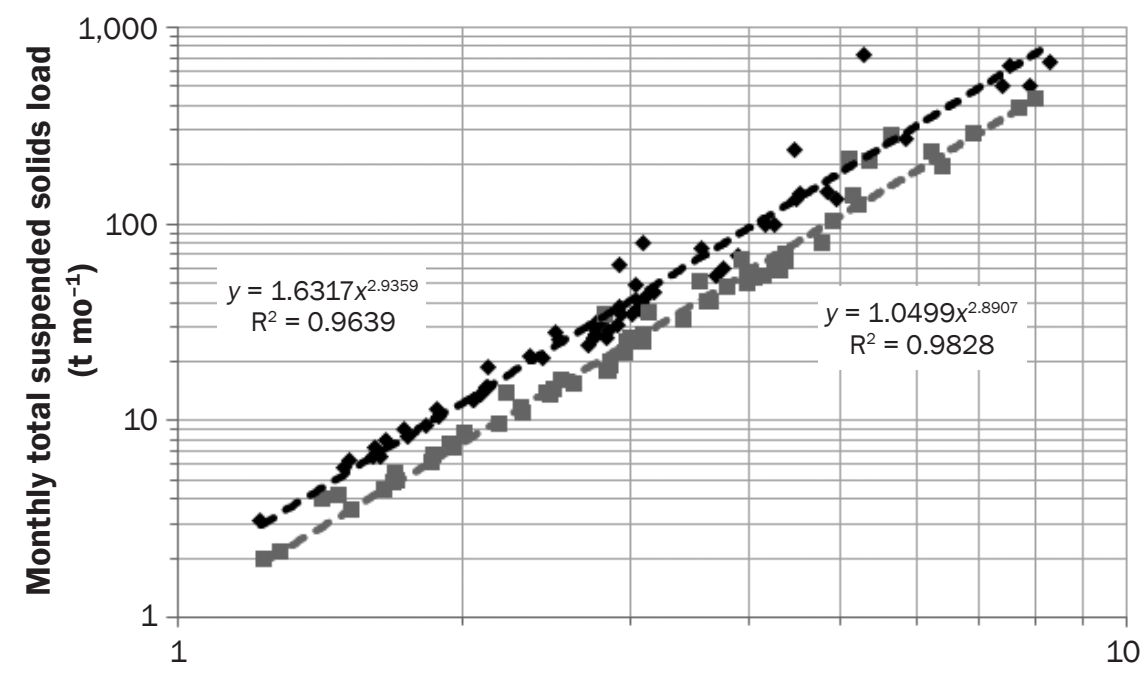

Mean monthly streamflow $\left(\mathrm{m}^{3} \mathrm{~s}^{-1}\right)$

\section{Legend}

Pre-BMPs: 1989 to 1993

Post-BMPs: 2004 to 2008

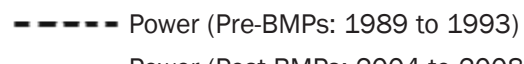

- = - = Power (Post-BMPs: 2004 to 2008)

data from pre- to post-BMP periods to determine the shift in the sediment rating curves. Minimum two years of continuous daily streamflow monitoring and at least 30 water quality grab sampling during a wide range of flow rates is needed for each of the pre- and the post-BMP periods to develop reliable sediment rating curves. For ungauged watersheds with limited monitoring data, watershed-scale water quality modeling (using SWAT, AGNPS, HSPF, or CANWET) can be used to fill-in data gaps.

Since both the land use and climate had changed negligibly from pre-BMP to post-
BMP periods, it was concluded that more than $40 \%$ reduction in the sediment loads in these two watersheds was the direct result of (and solely due to) the implementation of the numerous BMPs by local residents, growers, and the SSEA, and thus the amount of sediment loads entering the receiving waters and for the Severn Sound region to become delisted as an AOC on the Great Lakes.

\section{Acknowledgements}

We would like to thank the Natural Sciences and Engineering Research Council of Canada (NSERC), Ontario Ministry of Agriculture, Food and Rural Affairs (OMAFRA), Environment Canada (Great Lakes Sustainability Fund), Ontario Ministry of the Environment and Climate Change (MOECC), Lake Simcoe Region Conservation Authority (LSRCA), Greenland International Consulting Engineers for providing academic license and technical support for the CANWET model, and, in particular, the Severn Sound Environmental Association (SSEA) for generous financial support and invaluable in-kind support throughout the study.

\section{References}

Aber, J.D., S.V. Ollinger, A.C. Federer, P.B. Reich, M.L. Goulden, D.W. Kicklighter, J.M. Melillo, and R.G. Lathrop Jr. 1995. Predicting the effects of climate change on water yield and forest production in the northeastern United States. Climate Research 5: 207-222.

Ahmed, S., A. Singh, R. Rudra, and B. Gharabaghi. 2013. Comparison of CANWET and HSPF for water budget and water quality modeling in rural Ontario. Water Quality Research Journal of Canada 49(1):53-71.

\section{Figure 5}

Hog Creek monthly sediment load (a) calibration and (b) validation for pre-best management practice (BMP) period (1989 to 1993).

(a)

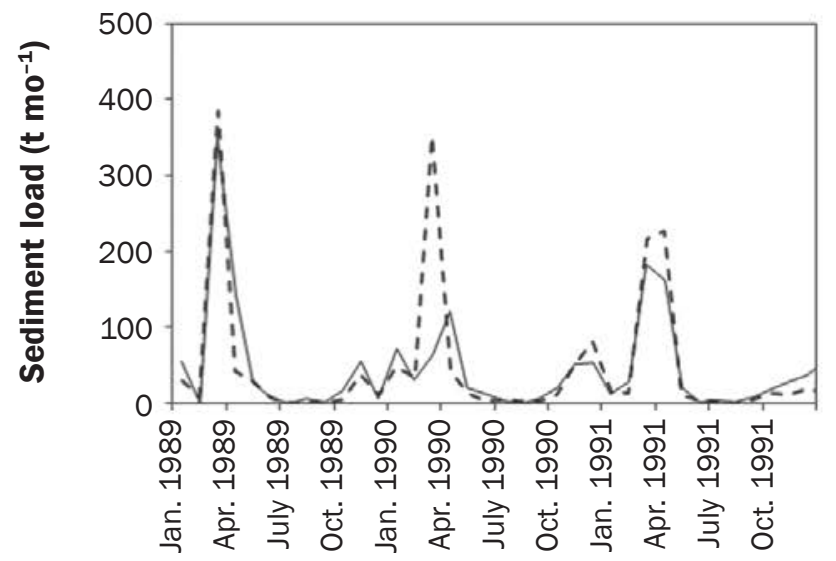

(b)

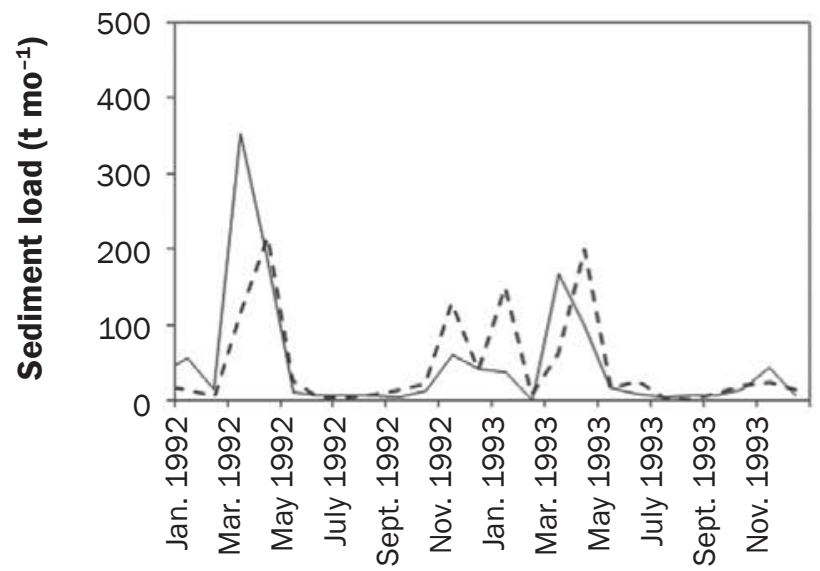

\section{Legend}

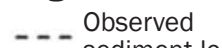

sediment load
Simulated

sediment load 


\section{Figure 6}

Hog Creek monthly sediment load (a) calibration and (b) validation for post-best management practice (BMP) period (2004 to 2008).

(a)

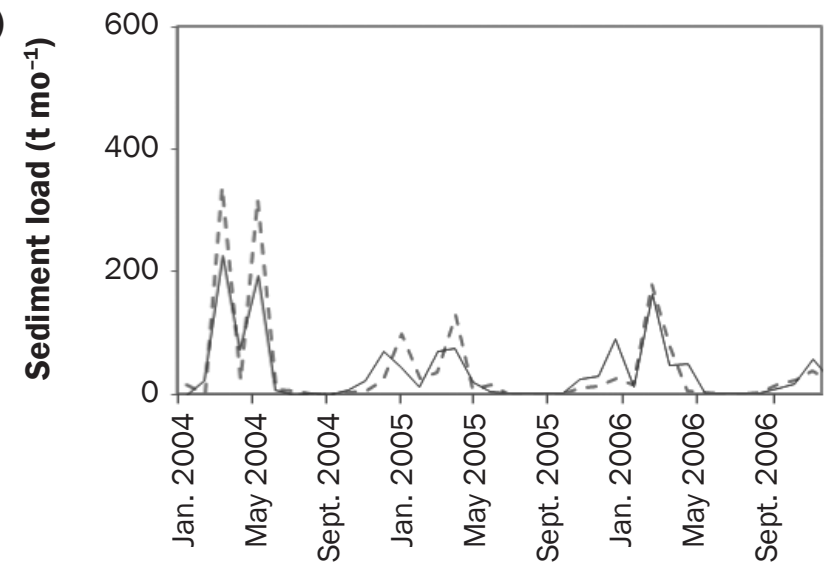

Legend

- - - Observed

sediment load (b)

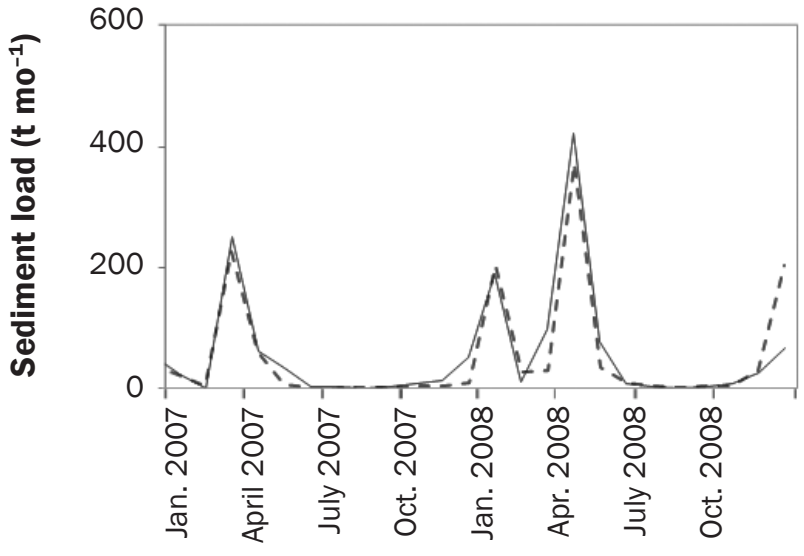

\section{Figure 7}

Sturgeon River monthly sediment load (a) calibration and (b) validation for pre-best management practice (BMP) period (1989 to 1993).

(a)

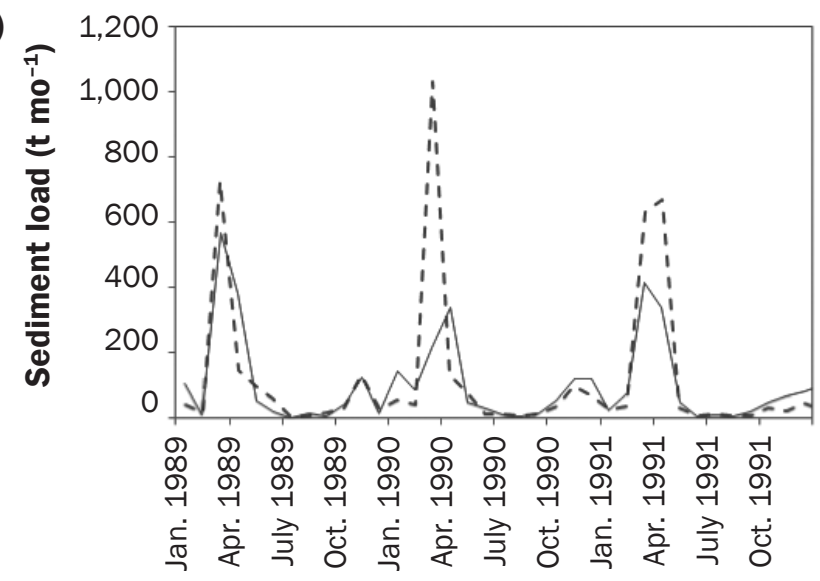

(b)

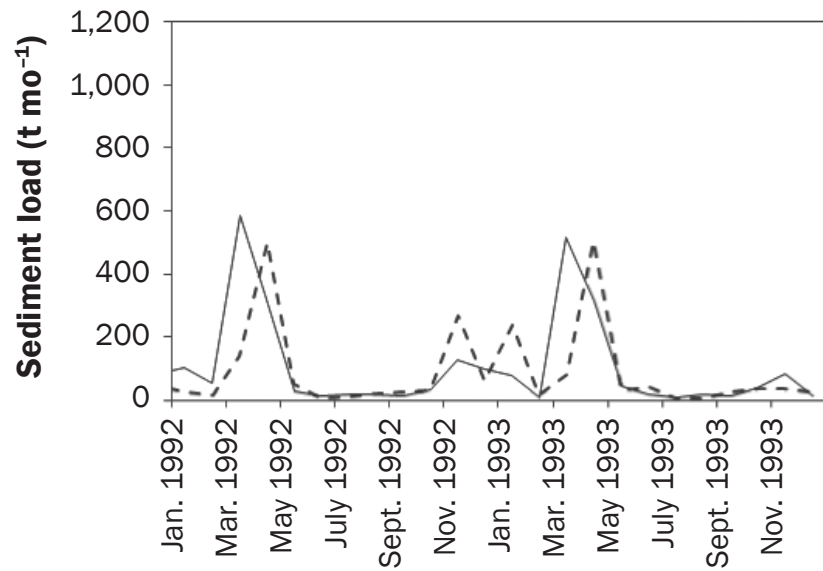

Legend

- - Observed

sediment load

Simulated sediment load

Alemayehu, D., R. Srinivasan, and P. Daggupati. 2014 Application of soil and water assessment tool model to estimate sediment yield in Kaw Lake. American Journal of Environmental Sciences 10(6):530-545.

Arabi, M., R.S. Govindaraju, and M.M. Hantush. 2007. A probabilistic approach for analysis of uncertainty in the evaluation of watershed management practices. Journal of Hydrology 333:459-471.

Artita, K.S., P. Kaini, and J.W. Nicklow. 2013. Examining the possibilities: Generating alternative watershed-scale BMP designs with evolutionary algorithms. Water Resources Management 27(11):3849-3863.
Asnaashari, A., B. Gharabaghi, E. McBean, and A.A. Mahboubi. 2015. Reservoir management under predictable climate variability and change. Journal of Water and Climate Change 6 (3):472-485.

Atieh, M., B. Gharabaghi, and R. Rudra. 2015. Entropybased neural networks model for flow duration curves at ungauged sites. Journal of Hydrology 529:1007-1020.

Bai, J., H. Ouyang, and R. Xiao. 2010. Spatial variability of soil carbon, nitrogen, and phosphorous content and storage in an alpine wetland in the Qinghai-Tibet Plateau, China. Australian Journal of Soil Research 48(8):730-736.
Baker, J.L., M.J. Helmers, and J.M. Laflen. 2006. Water management practices: Rainfed cropland. In Environmental Benefits of Conservation on Cropland: The Status of Our Knowledge, ed. M. Schnepf and C. Craig. Ankeny, Iowa: Soil and Water Conservation Society. Boyer, A. 2006. Reducing Bacteria with Best Management Practices. Dover, DE: Delaware Department of Natural Resources and Environmental Control.

Bracmort, K.S., M.Arabi, J.R. Frankenberger, B.A. Engel, and J.G. Arnold. 2006. Modeling long-term water quality impact of structural BMPs. Transactions of the American 


\section{Figure 8}

Sturgeon River monthly sediment load (a) calibration and (b) validation for post-best management practice (BMP) period (2004 to 2008).

(a)

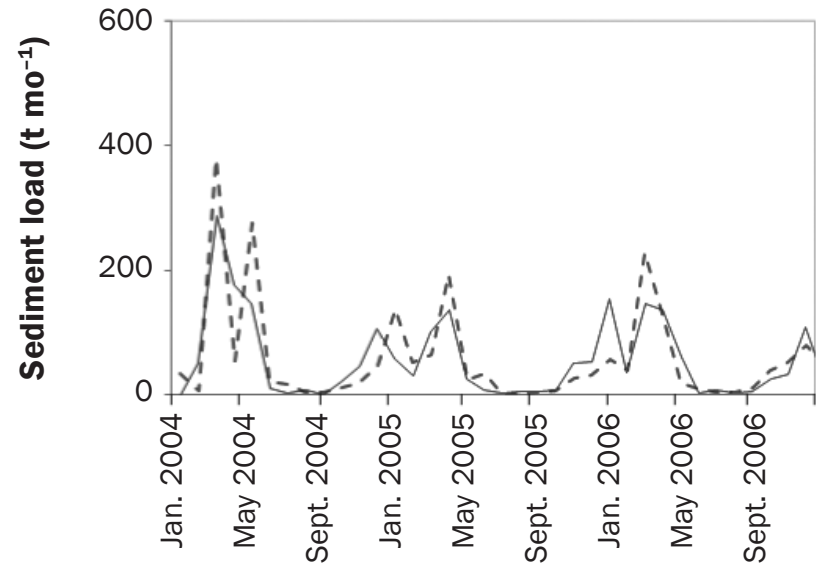

(b)

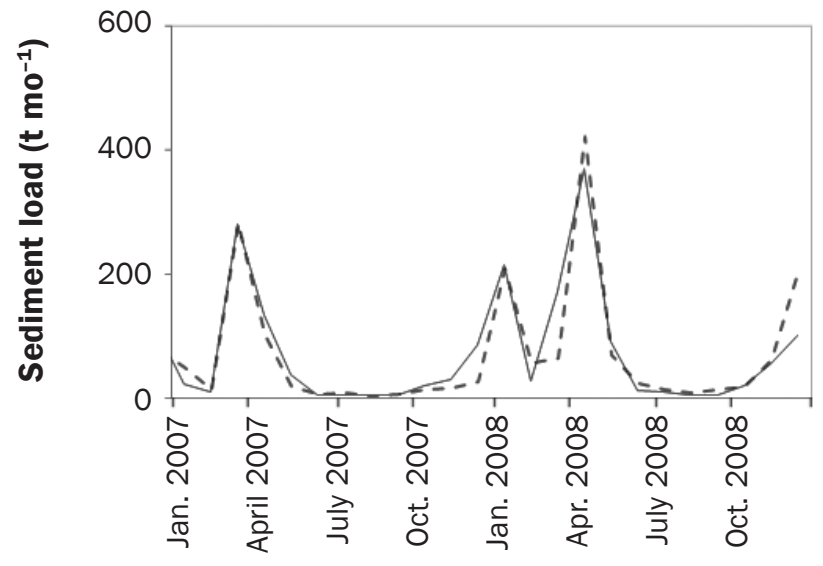

Legend

- - Observed

sediment load

Table 4

Statistical coefficients or measures for model evaluation and their range of variability.

\begin{tabular}{lll}
\hline Coefficient or measure & Equation & Range \\
\hline Coefficient of determination & $\mathrm{R}^{2}=\left[\frac{\sum_{i=1}^{n}\left(\mathrm{O}_{i}-\overline{\mathrm{O}}\right)\left(\mathrm{P}_{i}-\overline{\mathrm{P}}\right)}{\sqrt{\sum_{i=1}^{n}\left(\mathrm{O}_{i}-\overline{\mathrm{O}}\right)^{2}} \sqrt{\sum_{i=1}^{n}\left(\mathrm{P}_{i}-\overline{\mathrm{P}}\right)^{2}}}\right]^{2}$ & 0 to 1
\end{tabular}

Root mean square error

$$
\text { RMSE }=\sqrt{\frac{\sum_{i=1}^{n}\left(P_{i}-O_{i}\right)^{2}}{n}}
$$

0 to $\infty$

Index of agreement

(Willmout 1984)

$$
\mathrm{D}=1-\frac{\sum_{i=1}^{n}\left(\mathrm{O}_{i}-\mathrm{P}_{i}\right)^{2}}{\sum_{i=1}^{n}\left(\left|\mathrm{P}_{i}-\overline{\mathrm{O}}\right|+\left|\mathrm{O}_{i}-\overline{\mathrm{O}}\right|\right)^{2}}
$$

Note: $n=$ number of observations. $\mathrm{O}_{i}$ and $\mathrm{P}_{i}=$ observed and predicted values at the time step $i$. $\overline{\mathrm{O}}$ and $\overline{\mathrm{P}}=$ mean of observed predicted values at the time step $i$.

\section{Table 5}

\begin{tabular}{|c|c|c|c|c|c|c|c|c|c|}
\hline \multirow[b]{3}{*}{ Watershed } & \multirow{3}{*}{$\begin{array}{l}\text { Statistical } \\
\text { coefficient }\end{array}$} & \multicolumn{4}{|c|}{ Streamflow $\left(\mathrm{m}^{3} \mathrm{~s}^{-1}\right)$} & \multicolumn{4}{|c|}{ Sediment load $\left(\mathrm{t} \mathrm{mo}^{-1}\right)$} \\
\hline & & \multicolumn{2}{|l|}{ Pre-BMP } & \multicolumn{2}{|l|}{ Post-BMP } & \multicolumn{2}{|l|}{ Pre-BMP } & \multicolumn{2}{|l|}{ Post-BMP } \\
\hline & & Calibration & Validation & Calibration & Validation & Calibration & Validation & Calibration & Validation \\
\hline \multirow[t]{3}{*}{ Hog Creek } & $\mathrm{R}^{2}$ & 0.79 & 0.74 & 0.91 & 0.96 & 0.80 & 0.63 & 0.91 & 0.93 \\
\hline & RMSE & 1.27 & 1.48 & 1.02 & 1.80 & 0.06 & 0.06 & 0.04 & 0.04 \\
\hline & $\mathrm{D}$ & 0.88 & 0.98 & 0.95 & 0.98 & 0.87 & 0.76 & 0.91 & 0.96 \\
\hline \multirow[t]{3}{*}{ Sturgeon River } & $\mathrm{R}^{2}$ & 0.70 & 0.71 & 0.73 & 0.87 & 0.74 & 0.53 & 0.83 & 0.93 \\
\hline & RMSE & 1.54 & 1.45 & 1.45 & 2.12 & 0.16 & 0.15 & 0.05 & 0.04 \\
\hline & D & 0.81 & 0.98 & 0.82 & 0.98 & 0.77 & 0.69 & 0.89 & 0.96 \\
\hline
\end{tabular}

Canadian Nutrient and Water Evaluation Tool (CANWET) model statistics for monthly streamflow and sediment load.

Notes: $\mathrm{BMP}=$ best management practices. RMSE = root mean square error. $\mathrm{D}=$ index of agreement. $\mathrm{R}^{2}=$ coefficient of determination. 
Society of Agricultural and Biological Engineers (ASABE) 49(2):367-374.

Bracmort, K.S., B.A. Engel, and J.R. Frankenberger. 2004 Evaluation of structural best management practices 20 years after installation: Black Creek Watershed, Indiana. Journal of Soil and Water Conservation 59(5):191-196.

Brooks, E.S., S.M. Saia, J. Boll, L. Wetzel, Z.M. Easton, and

T.S. Steenhuis. 2015. Assessing BMP effectiveness and guiding BMP planning using process-based modeling. Journal of the American Water Resources Association 51(2):343-358.

Bryant, R.B., T.L. Veith, P.J.A. Kleinman, and W.J Gburek. 2008. Cannonsville Reservoir and Town Brook watersheds: Documenting conservation efforts to protect New York City's drinking water. Journal of Soil and Water Conservation 63:(6):339-344, doi:10.2489/ jswc.63.6.339.

Bumbudsanpharoke, W., D. Moran, and C. Hall. 2009. Exploring perspectives of environmental best management practices in Thai agriculture: An application of Q-methodology. Environmental Conservation 36(3)225-234.

Busteed, P.R., D.E. Storm, M.J. White, and S.H. Stoodley. 2009. Using SWAT to target critical source sediment and phosphorus areas in the Wister lake basin, USA. American Journal of Environmental Sciences 5(2):156-163.

Chapi, K., R. Rudra, S. Ahmed, A. Khan, and B. Gharabaghi. 2014. Spatial-temporal dynamics of runoff generation areas in a small agricultural watershed in southern Ontario. Journal of Water Resource and Protection $7(1): 14-40$

Chaubey, I., L. Chiang, M.W. Gitau, and S. Mohamed 2010. Effectiveness of best management practices in improving water quality in a pasture-dominated watershed. Journal of Soil and Water Conservation 65(6):424-437, doi:10. 2489/jswc.65.6.424.

Cook, C. M. 1999. A review of agricultural and urban best management practices for the removal of phosphorus removal, PUBL-SS-943-99, 73 pp. Madison, Wisconsin: Bureau of Integrated Science Services, Wisconsin Department of Natural Resources.

Daggupati, P., K.R. Douglas-Mankin, A.Y. Sheshukov, P.L. Barnes, and D.L. Devlin. 2011. Field-level targeting using SWAT: Mapping output FROM HRUs to fields and assessing limitations of GIS input data. Transactions of the American Society of Agricultural and Biological Engineers 132(2):501-514.

Daniels, R.B., and J.W. Gilliam. 1996. Sediment and chemical load Removal by grass and riparian filters. Soil Science Society of America Journal 60:246-251.

Daroub, S.H., T.A. Lang, O.A. Diaz, and S. Grunwald. 2009 Long-term water quality trends after implementing best management practices in South Florida. Journal of Environmental Quality 38(4):1683-1693.

Das, S., R. Rudra, B. Gharabaghi, S. Gebremeskel, P.K. Goel, and W.T. Dickinson 2008. Applicability of AnnAGNPS for Ontario conditions. Canadian Biosystems Engineering 50(1):1-11.

Dechmi, F., and A. Skhiri. 2013. Evaluation of best management practices under intensive irrigation using SWAT model. Agricultural Water Management 123:55-64.

Dinnes, D.L. 2004. Assessment of practices to reduce nitrogen and phosphorous nonpoint source pollution of Iowa's surface waters. Ames and Des Moines, Iowa: Prepared for the Iowa Department of Natural Resources in Cooperation with the USDA Agricultural Research Service (ARS) National Soil Tilth Laboratory.

DPRA Inc. 1989. An evaluation of the cost effectiveness of agricultural best management practices and publicly owned treatment works in controlling phosphorous pollution in the Great Lakes Basin. Report to the US Environmental Protection Agency (USEPA), Contract No. 68-01-7047, 1773 pp. Manhattan, KS: DPRA Incorporated.

Easton, Z.M., M.T. Walter, and T.S. Steenhuis. 2008. Combined monitoring and modeling indicate the most effective agricultural best management practices. Journal of Environmental Quality 37(5):1798-1809.

Gassman, P.W. , J.A. Tisl, E.A. Palas, C.L. Fields, T.M Isenhart, K.E. Schilling, C.F. Wolter, L.S. Seigley, and M.J. Helmers. 2010. Conservation practice establishment in two northeast Iowa watersheds: Strategies, water quality implications, and lessons learned. Journal of Soil and Water Conservation 65(6):381-392, doi:10.2489/jswc.65.6.381

Gazendam, E., B. Gharabaghi, E. McBean, H. Whiteley, and R. Kostaschuk. 2009. Ranking of waterways susceptible to adverse stormwater effects. Canadian Water Resources Journal 34(3):205-228.

Ghebremichael, L., and M. Watzin. 2008. An Environmental Accounting System to Track Nonpoint Source Phosphorous Pollution in the Lake Champlain Basin: Second Year Report. Technical Report No. 60. Burlington, VT: University of Vermont, Rubenstein School of Environment and Natural Resources.

Giri, S., and A.P. Nejadhashemi. 2014. Application of analytical hierarchy process for effective selection of agricultural best management practices. Journal of Environmental Management 132:165-177.

Giri, S., A.P. Nejadhashemi, and S.A. Woznicki. 2012. Evaluation of targeting methods for implementation of best management practices in the Saginaw River Watershed. Journal of Environmental Management 103:24-40.

Gitau, M.W., W.J. Gburek, and A.R. Jarrett. 2005. A tool for estimating best management practice effectiveness for phosphorous pollution control. Journal of Soil Water Conservation 60(1):1-10.

Glysson, G.D. 1987. Sediment rating curves. Open File Reports 87-87-218. Reston,VA: US Geological Survey.

Grady, C.A.,A.P. Reimer, J. Frankenberger, and L.S. Prokopy. 2013. Locating existing best management practices within a watershed: The value of multiple methods.
Journal of the American Water Resources Association 49(4):883-895

Greenland International Consulting LTD. 2007. Canadian nutrient and water evaluation tool: user's manual. Ontario, Canada: Greenland International Consulting.

Guo, Q., G. England, and C.E. Johnston. 2008. Development of certification guidelines for manufactured stormwater BMPs. American Society of Civil Engineers (ASCE)/ Environmental and Water Resources Institute (EWRI) Task Committee on Guidelines for Certification of Manufactured Stormwater Best Management Practices.

Heathwaite, A.L., P. Griffiths, and R.J. Parkinson. 1998. Nitrogen and phosphorous in runoff from grassland with buffer strips following application of fertilizers and manures. Soil Use Management 14:142-148.

Hernandez, E.A., and V. Uddameri. 2015. Selecting agricultural best management practices for water conservation and quality improvements using Atanassov's Intuitionistic Fuzzy Sets. Water Resources Management 24(15):4589-4612.

Houlahan, J.E., and C.S. Findlay. 2004. Estimating the 'critical' distance at which adjacent land-use degrades wetland water and sediment quality. Landscape Ecology 19:677-690.

Inamdarm, S., and A. Naumov. 2006. Assessment of sediment yields for a mixed-landuse Great Lakes Watershed: Lessons from field measurements and modeling. International Association of Great Lakes Research 32:471-488

Jang, T., G. Vellidis, J.B. Hyman, E. Brooks, L.A. Kurkalova, J. Boll, and J. Cho. 2013. Model for prioritizing best management practice implementation: Sediment load reduction. Environmental Management 51(1):209-224.

Jeffrey, S.R., S. Koeckhoven, D. Trautman, B. Dollevoet, J.R. Unterschultz, and C. Ross. 2014. Economics of riparian beneficial management practices for improved water quality: A representative farm analysis in the Canadian Prairie region. Canadian Water Resources Journal 39(4):449-461.

Karamouz, M., M. Taheriyoun, A. Baghvand, H. Tavakolifar, and F. Emami. 2010. Optimization of watershed control strategies for reservoir eutrophication management. Journal of Irrigation and Drainage Engineering 136(12):847-861.

Kurkalova, L.A. 2015. Cost-effective placement of best management practices in a watershed: Lessons learned from conservation effects assessment project. Journal of the American Water Resources Association 51(2):359-372.

Lam, Q.D., B. Schmalz, and N. Fohrer. 2011. The impact of agricultural Best Management Practices on water quality in a North German lowland catchment. Environmental Monitoring and Assessment 183:351-379.

Lee, T., M.E. Rister, B. Narashimhan, R. Srinivasan, D. Andrew, and M.R. Ernst. 2010. Evaluation and spatially distributed analyses of proposed cost-effective bmps for reducing phosphorous level in cedar creek 
reservoir, Texas. Transactions of the American Society of Agricultural and Biological Engineers 53(5):1619-1627. Lemke,A.M., K.G. Kirkham,T.T. Lindenbaum, M.E.Herbert, T.H.Tear, W.L. Perry, and J.R. Herkert. 2011. Evaluating agricultural best management practices in tile-drained subwatersheds of the Mackinaw River, Illinois. Journal of Environmental Quality 40(4):1215-1228.

Lin, C.E., C.M. Kao, Y.C. Lai, W.L. Shan, and C.Y. Wu. 2009. Application of integrated GIS and multimedia modeling on NPS pollution evaluation. Environmental Monitoring and Assessment 158:319-331.

Liu, Y., V.F. Bralts, and B.A. Engel. 2015. Evaluating the effectiveness of management practices on hydrology and water quality at watershed scale with a rainfall-runoff model. Science of the Total Environment 511:298-308.

Liu, Y., W. Yang, Z. Yu, I. Lung, and B. Gharabaghi. 2015 Estimating sediment yield from upland and channel erosion at a watershed scale using SWAT. Water Resources Management 29(5):1399-1412.

Livesey, R.H. 1975. Corps of Engineers method for predicting sediment yields. Present and prospective technology for predicting sediment yields and sources,ARS-S-40, pp. 16-32. Washington, DC: USDA Agricultural Research Service.

Lizotte Jr., R.E., S.S. Knight, M.A. Locke, and R.L. Bingner. 2014. Influence of integrated watershed-scale agricultural conservation practices on lake water quality. Journal of Soil and Water Conservation 69(2):160-170, doi:10.2489/jswc.69.2.160.

Lugbill, J. 1990. Potomac River Basin nutrient inventory. Washington, DC: Metropolitan Washington Council of Governments.

Maringanti, C., I. Chaubey, M. Arabi, and B. Engel. 2011. Application of a multi-objective optimization method to provide least cost alternatives for NPS pollution control. Environmental Management 48(3):448-461.

Meals, D.W. 2001. Lake Champlain Basin Agricultural Watersheds Section 319 National Monitoring Program Project: Final Project Report, May 1994-November 2000. Montpelier, VT: Vermont Department of Environmental Conservation.

Melcher, C.P., and S.K. Skagen. 2005. Grass buffers for playas in agricultural landscapes: A literature synthesis. Open-File Report 2005-1220. Fort Collins, CO: US Geological Survey.

Merriman, K.R., M.W. Gitau, and I. Chaubey. 2009. A tool for estimating best management practice effectiveness in Arkansas. Applied Engineering in Agriculture 25(2):199-213.

Mikkelsen, R.L., and J.W. Gilliam. 1995. Rating and losses of animal wastes in runoff from agricultural fields. In Seventh International Symposium on Agricultural and Food Processing Wastes, 185-189, ed. Charles Ross. Chicago, IL. American Society of Agricultural Engineers ASAE Publication 7-95.

Mostaghimi, S., S.W. Park, R.A. Cooke, and S.Y. Wang. 1997. Assessment of management alternatives on a small agricultural watershed. Water Research 31(8):1867-1878.

Mueller-Warrant, G.W., S.M. Griffith, G.W.Whittaker, G.M. Banowetz, W.F. Pfender, T.S. Garcia, and G.R. Giannico. 2012. Impact of land use patterns and agricultural practices on water quality in the Calapooia River Basin of western Oregon. Journal of Soil and Water Conservation 67(3):183-201, doi:10.2489/jswc.67.3.183.

Neff, B.P., S.M. Day, A.R. Piggott, and L.M. Fuller. 2005. Base flow in the Great Lakes Basin. US Geological Survey Scientific Investigations Report 2005-5217, 23p.

Nietch, C.T., M. Borst, and J.P. Schubauer-Berigan. 2005 Risk management of sediment stress: A framework for sediment risk management research. Environmental Management 36(2):175-194.

O'Connor, T.P., and J. Rossi. 2009. Monitoring of a best management practice wetland before and after maintenance. Journal of Environmental Engineering 135(11):1145-1154

Patty, L., B. Real, and J.J. Gril. 1997. The use of grassed buffer strips to remove pesticides, nitrate, and soluble phosphorous compounds from runoff water. Pesticide Science 49:243-251.

Pennsylvania State University. 1992. Nonpoint Source Database. University Park, PA: Pennsylvania State University, Department of Agricultural and Biological Engineering.

Perry-Hill, R. and L. Prokopy. 2015 Improving environmental management on small-scale farms: Perspectives of extension educators and horse farm operators. Environmental Management 55(1):31-42.

Prokopy, L.S., K. Floress, D. Klotthor-Weinkauf, and A. Baumgart-Getz. 2008. Determinants of agricultural best management practice adoption: Evidence from the literature. Journal of Soil and Water Conservation 63(5):300-311, doi:10.2489/jswc.63.5.300.

Richardson, C.W., D.A. Bucks, and E.J. Sadler. 2008. The conservation effects assessment project benchmark watersheds: Synthesis of preliminary findings. Journal of Soil and Water Conservation 63(6):590-604, doi:10.2489/jswc.63.6.590.

Ritter, W.F., and A. Shirmohammadi. 2001. Agricultural Nonpoint Source Pollution: Watershed Management and Hydrology. Boca Raton, FL: CRC Press.

Robinson, C.A., M. Ghaffarzadeh, and R. M. Cruse. 1996 Vegetative filter strip effects on sediment concentration in cropland runoff. Journal of Soil and Water Conservation 50(3): 227-230.

Rudra, R.P., B. Gharabaghi, S. Sebti, N. Gupta, and A. Moharir. 2010. GDVFS: A new toolkit for analysis and design of vegetative filter strips using VFSMOD. Water Quality Research Journal of Canada 45(1):59-68.

Sattar,A.M., and B. Gharabaghi.2015. Gene expression models for prediction of longitudinal dispersion coefficient in streams. Journal of Hydrology 524:587-596.

Schnepf, F.M., and C. Cox. 2006. Environmental benefits of conservation on croplands: The status of our knowledge. Ankeny, IA: Soil and Water Conservation Society.
SEPA (Scottish Environment Protection Agency). 2010. Agricultural best management practices guidance manual. SERA 17 (Southern Extension and Research Activity). 2009. Best Management Practice (BMP) Fact Sheets.

SSEA (Severn Sound Environmental Association). 2002. The status of restoration and delisting of Severn Sound as an area of concern. Severn Sound, remedial action plan, stage 3 report. Ontario, Canada: Severn Sound.

SSRAP (Severn Sound Remedial Action Plan). 1993. Stage 2 Report: A strategy for restoring the Severn Sound ecosystem and delisting Severn Sound as an Area of Concern. Toronto

Singer, S., T. Cheng, M. Scafe, K. Sherman, G. Shiekh, and W. Zaia. 2002. The groundwater resources of the Severn Sound remedial action plan area. Ontario, Canada: Severn Sound Environmental Association.

Singh, A., R.P. Rudra, and B. Gharabaghi. 2012. Evaluation of CANWET model for hydrologic simulations for upper Canagagigue Creek Watershed in southern Ontario. Canadian Biosystems Engineering 54(1):7-18.

Smith, D.R., W. Francesconi, S.J. Livingston, and C. Huang. 2015. Phosphorus losses from monitored fields with conservation practices in the Lake Erie Basin, USA. Ambio 44(2):319-331

Smith, C.M., J.M. Peterson, and J.C. Leatherman. 2007. Attitudes of Great Plains producers about best management practices, conservation programs, and water quality. Journal of Soil and Water Conservation 62(5):97-103

Sommerlot, A.R., A. Pouyan Nejadhashemi, S.A. Woznicki, and M.D. Prohaska. 2013. Evaluating the impact of field-scale management strategies on sediment transport to the watershed outlet. Journal of Environmental Management 128:735-748.

Trenouth, W., and B. Gharabaghi. 2015. Event-based soil loss models for construction sites. Journal of Hydrology 524:780-788.

Tuppad, P., N. Kannan, R. Srinivasan, C.G. Rossi, and J.G. Arnold. 2010a. Simulation of agricultural management alternatives for watershed protection. Water Resources Management 24(12):3115-3144.

Tuppad, P., C. Santhi, and R. Srinivasan. 2010b. Assessing BMP effectiveness: Multiprocedure analysis of observed water quality data. Environmental Monitoring and Assessment 170:315-329.

Van Liew, M.W., S. Feng, and T.B. Pathak. 2013. Assessing climate change impacts on water balance, runoff, and water quality at the field scale for four locations in the heartland. Transactions of the American Society of Agricultural and Biological Engineers 56(3):883-900.

Wenger, S. 1999. A review of the scientific literature on riparian buffer width, extent and vegetation, $59 \mathrm{pp}$. Athens, GA: Institute of Ecology, University of Georgia. Whitfield, P.H, and A.J. Cannon. 2000. Recent variations in climate and hydrology in Canada. Canadian Water Resources Journal 25(1):19-65. 
Wischmeier, W.H., and D.D. Smith. 1965. Predicting rainfall erosion losses from cropland east of the Rocky Mountains: Guide for selection of practices for soil and water conservation planning. USDA Agriculture Handbook, p. 282. Washington, DC: US Government Printing Office.

Wu, J., S.L. Yu, and R. Zou. 2006. A water qualitybased approach for watershed wide BMP strategies. Journal of the American Water Resources Association 42(5):1193-1204.

Yagow, G., T. Dillaha, J. Pease, D. Kibler, and D. Bosch. 2002.A BMP database for nutrient Removal. In Proceedings of the Conference on TMDL Environmental Regulations, Fort Worth, Texas, March 11-13, American Society of Agricultural Engineers Publication Number 701P0102, pp. 250-255.

Yang, Q., G.A. Benoy, T.L. Chow, J.-L. Daigle, C.P.-A. Bourque, and F.-R. Meng. 2012. Using the soil and water assessment tool to estimate achievable water quality targets through implementation of beneficial management practices in an agricultural watershed. Journal of Environmental Quality 41(1):64-72.

Yang, Q., L.F. Leon, W.G. Booty, I.W. Wong, C. McCrimmon, P. Fong, P. Michiels, J. Vanrobaeys, and G. Benoy. 2014. Land use change impacts on water quality in three Lake Winnipeg watersheds. Journal of Environmental Quality 43(5):1690-1701.

Yang, Q., F.-R. Meng, Z. Zhao, T.L. Chow, G. Benoy, H.W. Rees, and C.P.-A. Bourque. 2009a. Assessing the impacts of flow diversion terraces on stream water and sediment yields at a watershed level using SWAT model. Agriculture, Ecosystems and Environment 132:23-31.

Yang, Q., Z. Zhao, T.L. Chow, H.W. Rees, C.P. Bourque, and F.-R. Meng. 2009b. Using GIS and a digital elevation model to assess the effectiveness of variable grade flow diversion terraces in reducing soil erosion in northwestern New Brunswick, Canada. Hydrological Processes 23(23):3271-3280.

Yuan, Y., S.M. Dabney, and R.L. Bingner. 2002. Cost effectiveness of agricultural BMPs for sediment reduction in the Mississippi Delta. Journal of Soil and Water Conservation 57(5):259-267.

Zhang, X., L.A. Vincent, W.D. Hog, and A. Niitsoo. 2000. Temperature and precipitation trends in Canada during the 20th Century. Atmosphere-Ocean 38(3):395-429.

Zhou, X., M. J. Helmers, M. Al-kaisi, and H.M. Hanna. 2009. Cost-effectiveness and Cost-benefit analysis of conservation management practices for sediment Removal in an Iowa agricultural watershed. Journal of Soil and Water Conservation 64(5):314-323, doi:10.2489/jswc.64.5.314. 